\title{
Factors Influencing Student's Perceptions Towards E-Learning Adoption During COVID-19 Pandemic: A Developing Country Context
}

\author{
Vusumuzi Maphosa ${ }^{1 *}$ (D)
}

${ }^{1}$ Lupane State University, ZIMBABWE

*Corresponding Author: vmaphosa@lsu.ac.zw

Citation: Maphosa, V. (2021). Factors Influencing Student's Perceptions Towards E-Learning Adoption During COVID-19 Pandemic: A Developing Country Context. European Journal of Interactive Multimedia and Education, 2(2), e02109. https://doi.org/10.30935/ejimed/11000

\begin{abstract}
After the coronavirus outbreak, face-to-face teaching was interrupted partially or entirely, and several universities adopted a variety of remote-based learning approaches. Most institutions in the developing world were not ready for such an abrupt change. Access to appropriate devices that facilitate students' effective learning in developing countries remains a challenge. This study evaluates university students' perceptions regarding e-learning deployment during COVID-19 and the factors that affected usage. The quantitative study employed an adapted Unified Theory of Acceptance and Use of Technology model to guide the research process. The model has five exogenous and two endogenous variables. The survey research was administered to randomly selected undergraduate University students, with 314 completing the online questionnaire. The results show that performance expectancy, effort expectancy, and the facilitating conditions positively influenced the students' behavioural intentions to use Moodle. Thus, the students had a positive perception of online learning. Results indicate a significant loss of learning due to the unavailability of technology and the cost of data; nevertheless, students agreed that online learning represents the future of teaching and learning. The findings also show that subsidised access to resources and materials is critical for the effective adoption of e-learning. This study's output provides valuable information to policymakers and researchers regarding students' perceptions and the state of elearning at institutions of higher learning.
\end{abstract}

Keywords: COVID-19 pandemic, face-to-face learning, blended learning, UTAUT, Moodle

Received: 2 Jan. 2021 - Accepted: 5 Apr. 2021

\section{INTRODUCTION}

The outbreak of the COVID-19 pandemic in December 2019 caused by severe acute respiratory syndrome coronavirus 2 (SARSCoV-2) caused unprecedented disruptions in human activity, including education (Mouchantaf, 2020). Governments forced citizens to practice a new way of life that limited personal contact and subjected people to several restrictive measures, known as lockdowns. To contain its rapid spreading, over $70 \%$ of educational institutions, from early childhood learning to higher learning institutions, closed schools, and suspended face-to-face teaching, affecting over 1.5 billion learners (Gupta et al., 2020). Zimbabwean universities, colleges, and schools were forced to close in March 2020, affecting over 4.56 million learners (OCHA, 2020). Face-to-face learning was barred, and learners adopted remote-based learning. For the first time, higher education institutions in Zimbabwe migrated to the online environment to protect staff and learners' lives.

The migration to the online world was disruptive and had several limitations and difficulties for students. Students hurriedly left their campuses, with little time to adjust to the new norm; this demanded more financial resources for remote based learning. Students had not received any formal training on technology-based learning, and with no prior experience, students and their lecturers experimented using technologies as they transitioned to a fully online environment. It resulted in an unpleasant learning experience. The students would typically rely on campus-based facilities such as computer labs and WiFi facilities. This sudden shift caused anxiety among students as the university curriculum was for in-person learning, and institutions were unprepared for an abrupt shift due to a lack of resources to support emergency remote teaching. Lupane State University (LSU) installed Moodle and produced training materials for usage.

Connectivity is a significant setback in developing countries, with about $35 \%$ of the population having access to the internet compared to $80 \%$ in developed countries (World Bank, 2020). For example, over $79.3 \%$ of Georgia homes have broadband, with city homes slightly higher, at $86 \%$ (Basilaia \& Kvavadze, 2020). Schools are employing several solutions to ensure that teaching and learning continue, and this is due to limitations in digital access, as only $60 \%$ of the world's 
population is online (Tam \& El-Azar, 2020). Reports reveal that more than $50 \%$ of the schools in Africa have no access to electricity, and over $60 \%$ of the population has no access to broadband Internet (World Bank, 2020). By the end of 2019, 56.5\% of the Zimbabwean population had access to the internet, with the majority connecting through mobile phones (Internetworldstats, 2020).

Most university courses are delivered through traditional face-toface learning, and academic staff had no experience in teaching online, thus negatively affecting redesigning of content, lesson plans, and activities. Zimbabwean universities rely on face-to-face examinations, and students lack access to teaching and learning devices, cost of data, and limited support from institutions. Institutions that had adopted elearning platforms before the lockdown found it easy to migrate into the online world. The online environment offers 24-hour access to students' learning material, which improves the learning process as institutions move to the online environment. However, institutions are struggling to offer online examinations due to existing complex and significant challenges. This will significantly disrupt the semester and academic year.

The return to face-to-face traditional lecture delivery is uncertain since the COVID-19 pandemic cure remains uncertain, and students would learn from home. For many developing countries, COVID-19 has accelerated the adoption of modern tools that support remote-based teaching, and this has helped institutions leapfrog into adopting tools that support $21^{\text {st }}$-century learning. If there was no COVID-19 outbreak, most institutions would have continued offering traditional face-toface teaching with no plans to adopt modern technology-based teaching methods. Some researchers note that the pandemic disrupted a system that had long lost its relevance (Li \& Lalani, 2020). Previous research reveals that online learning platforms' can cover a course with about $50 \%$ less time than face-to-face learning (Li \& Lalani, 2020). The online environment supports self-directed learning, where students can revisit concepts and revise at their own time.

Electronic learning (e-learning) refers to the integration of ICT tools to support educational services. E-learning is ubiquitous, allowing access anywhere and anytime, very cheap to set up, and offers excellent flexibility and interactivity. The online environment offers students virtual labs and simulation tools that allow students to use video-based tools to access the labs and perform real-time experiments (Gamage et al., 2020). E-learning has achieved global recognition as it allows learners to access a vast educational content pool, enables learners to create content, learn independently, collaborate amongst themselves, and create new knowledge (Hoque \& Alam, 2010). Even though many educational institutions had started using e-learning, most Zimbabwean educational institutions lagged in adopting e-learning and making its use mandatory. It is only now, after the COVID-19 pandemic outbreak, that institutions realise how e-learning has become the only feasible and practical solution for continued learning.

Very few studies have been undertaken to evaluate students' perceptions regarding the implementation of remote-based teaching in a developing country such as Zimbabwe during the COVID-19 pandemic. The paper aims to contribute literature on students perceptions, which may provide insight for other developing countries. The study examines university students' perceptions and establishes the main factors that affected Moodle's successful usage after its launch during COVID-19. The paper's remaining sections are as follows: the following section reviews related studies regarding e-learning implementation and students' perceptions. The theoretical framework is then presented, followed by the methodology and data collection procedure. After that, the presentation of results and discussion follows. The paper then presents recommendations, limitations, and conclusions.

\section{LITERATURE REVIEW}

The role and popularity of information technology in society are evident, and its role in supporting education was apparent during the COVID-19 pandemic, where institutions migrated into the online world (Eltayeb et al., 2020). Large portions of the developed world have embraced the internet, virtual reality, and associated technologies to work and learn from home (Gamage et al., 2020). Scholars report that students prefer digital media to printed material to support the learning process (Salajegheh et al., 2016). Li and Lalani (2020) worry that some educational institutions are utilising traditional teacher-centred methods instead of adopting $21^{\text {st }}$-century learning techniques that support critical thinking, independent and learner-centred learning. Oyediran et al. (2020) point out that digital technologies allow learners to access rich multimedia material, which is more effective than printed material beyond space and time limitations. The $21^{\text {st }}$-century has witnessed an increase in the adoption of online learning approaches that support distance learning and blended-learning for campus and non-campus-based students (Rodriguesa et al., 2019). E-learning is a viable solution for people with tight and conflicting schedules that deny them opportunities to attend face-to-face classes. Alqahtani and Rajkhan (2020) posit that e-learning technologies enhance knowledge exchange between the students and the lecturer and strengthen communication channels, resulting in improved performance. Though it is evident that online learning offers more benefits to learners, there has been a slow uptake of online-based learning in most developing countries, and the COVID-19 pandemic will catapult institutions into adopting more sustainable and innovative learning solutions ( $\mathrm{Li} \&$ Lalani, 2020).

Gupta et al. (2020) posit that students are struggling to migrate into the online environment due to a lack of access to the internet and resources that support online learning. The sudden deep dive into the online environment happened when the students were least prepared to access the e-learning and with limited skills (Tam \& El-Azar, 2020). Nevertheless, the COVID-19 outbreak may have accelerated online learning systems' adoption more than any other event could have done, especially in developing countries. Successful implementation of elearning depends on the experiences of students and instructors to use various online learning tools. The success of e-learning requires the cooperation of students who should adjust from the traditional course offering and navigate through the latest technological terrain that has specific demands (Gelles et al., 2020). Enormous data costs and other disparities fuel inequalities in access to quality education, and these issues are widening the digital divide (Tam \& El-Azar, 2020).

In a study by Oyediran et al. (2020), Nigerian students reported that the high cost of ICT devices negatively affected e-learning adoption. Hurlbut (2018) noted that instructor feedback was one of the top predictors of adoption highlighted by students who successfully embraced an online course. Another study by Akuratiya and Meddage (2020) revealed that most students preferred blended learning, while less than $5 \%$ opted for traditional face-to-face learning. Another study 
in Malaysia also revealed that high data costs hindered learners from fully participating in online learning (Ramli et al., 2020). Sintema (2020) contended that students from developing countries with limited infrastructure found it challenging to migrate into the online environment fully. The movement from face-to-face to online learning was initially resisted as educators felt that in-class students performed better than the online ones.

Most educational institutions in developing countries struggled to transform their traditional courses for the online environment due to a lack of access to the internet and devices for students and lecturers (Gupta et al., 2020). Neuwirth et al. (2020) report that students had limited access to appropriate devices such as computers, webcams, internet, which affected their presence in the online environment. The scholars also see a lack of access to ICT devices by students in middle and low-income countries; for example, 34\% of students in Indonesia compared to 95\% in Sweden (Tam \& El-Azar, 2020).

A study conducted by Tan et al. (2009) revealed that students taught in class and those that took an online course scored similar marks during an examination. Previous research has shown that students retain about $60 \%$ more material when using online learning than about $10 \%$ when using the traditional in-class learning method (Li \& Lalani, 2020). Student performance results done through a systematic review revealed that students on an online and a hybrid format performed similar or better than those taking a traditional face-to-face course (Hurlbut, 2018). On some conducted tests, Harrell and Harris (2006) reported that online students did not out-perform traditional face-toface students.

The availability of open source and proprietary learning management systems has helped educational institutions to manage the transition into remote-based teaching and learning. Almaiah et al. (2020) assert that e-learning played a pivotal role during the pandemic in supporting student-centred learning as it enabled institutions to manage the learning process. Most universities worldwide migrated to online platforms in line with restrictions imposed on face-to-face gatherings and utilised platforms such as Moodle, Google Classroom, and Blackboard to ensure continued learning during the lockdown (Gupta et al., 2020; Maphosa, 2020). Reports reveal that 63 of the 64 American universities and 17 of the 21 South African universities moved into the online environment and used support tools such as ZOOM, Canvas, and Blackboard (Chaka, 2020). The Chinese Ministry of Education crafted a policy known as Suspending Classes Without Stopping Learning, which ensured that hundreds of millions of learners did not miss any learning as they stayed at home during the COVID-19 (Huang et al., 2020). Universities in Poland underwent significant transformations in their teaching to ensure that they smoothly migrate into the online environment without causing any disruptions (Ozadowicz, 2020). Gelles et al. (2020) note that universities that successfully migrated into the online environment strengthened communication with students through constant updates on assessments, additional resources, and grading policies.

Alqahtani and Rajkhan (2020) highlight that even some institutions that had implemented e-learning before the lockdown found it challenging to migrate during COVID-19 suddenly; this was worse for institutions that had no prior experience. Swartz et al. (2018) report that content and course delivered through technology should be adapted to the virtual environment effectively. Some Science, Technology, and Engineering universities in China partnered in developing computer-based experiments and assessment tools shared by their students (Gamage et al., 2020).

Anderson (2005) was cautious as he noted that communities who face equity challenges with traditional educational resources were likely to face more challenges as they move into the online environment. There is unequal access to the internet globally, with about $19 \%$ access in the developing world, and the pandemic has glaring magnified these inequalities with commentators arguing that access should be universal (Reglitz, 2020). Tam and El-Azar (2020) report that most developing countries struggle to participate online due to unreliable internet access. Gamage et al. (2020) contend that in the new norm, the internet is the medium to all forms of freedoms, such as the freedom of expression and assembly. Communities without internet access cannot enjoy these fundamental freedoms. For example, Zimbabwe's Constitution guarantees the right to education for all (Veritas, 2013); yet the country has the most expensive data in the world where one gigabyte costs USD75.00 (McCarthy, 2019), and without internet access, this right cannot be exercised.

Other governments assisted students in reducing the financial burden of going online. The Malaysian government provided students with free 30GB of data per month to support remote-based learning (Ramli, Majid, \& Badyalina, 2020). The South African government provided over 700000 new laptops for university students to support learning during the COVID-19 pandemic (businesstech, 2020). All university websites in South Africa have been zero-rated, ensuring that university students can access-learning content at zero cost (universityworldnews, 2020). Gelles et al. (2020) report that most students felt unprepared to transition into the online environment and felt that the communication they experienced with their professors was impersonal. For many developing countries, there is a need to develop learning management systems that rely on low bandwidth and can be effectively used with mobile phone devices to reduce device access barriers and improve completion rates (United Nations University, 2020). The main themes that emerged from the literature include infrastructural and device deficiencies, rapid migration, data costs, and communication with students.

\section{THEORETICAL FRAMEWORK}

The Unified Theory of Acceptance and Use of Technology (UTAUT) model provided the theoretical framework for guiding the study in evaluating university students' perceptions regarding online learning during the COVID-19 lockdown. The UTAUT by Venkatesh et al. (2003) evaluates the user's perceptions in accepting new technology, as shown in Figure 1. This study's adapted model has three determinants of the Behavioural Intention (BI) to actual use of an elearning platform (Performance Expectancy (PE), Effort Expectancy (EE), and Facilitating Condition (FC)). The facilitating conditions have three constructs (Support, Access, and Efficacy). The facilitating conditions construct directly determine usage behaviour. The model has five exogenous (PE, EE, FC-Support, FC-Access, FC-Efficacy) and two endogenous (BI and Actual Use) variables. The moderating variables (Age, Gender, Voluntariness, and Experience) were not used in this study as the researcher felt that the constructs did not influence the usage of Moodle by university students. Several scholars researching technology acceptance by students made similar assumptions, such as Raman et al. (2014); Liebenberg et al. (2018); 


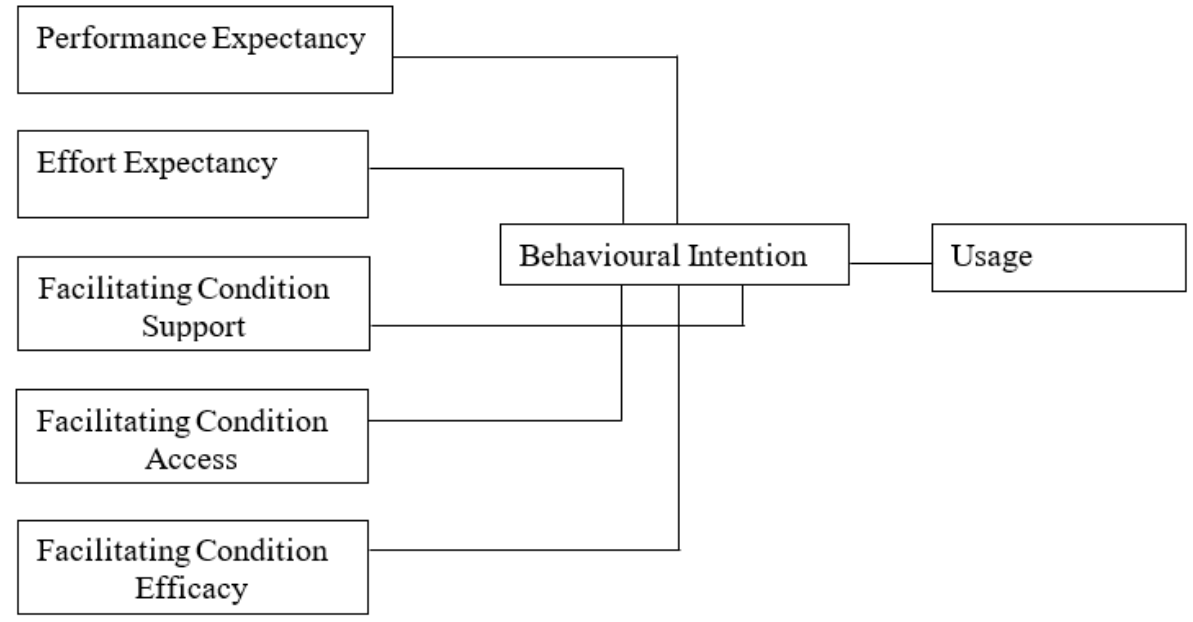

Figure 1. The adapted UTAUT model (Venkatesh et al., 2003)

Attuquayefio and Addo (2014); Kurt and Tingöy (2017); Nistor et al. (2014); Magsamen-Conrad et al. (2015), and Tan (2013), who investigated the adoption of various technologies by students.

\section{Hypotheses}

Multiple linear regression was used to test the following hypotheses, as depicted in Figure 1:

H1: PE will be a predictor of LSUs' BI toward using online learning.

$\mathrm{H} 2$ : EE will be a predictor of LSUs' BI toward using online learning.

H3: FC Support will be a predictor of LSUs' BI toward using online learning.

H4: FC Access will be a predictor of LSUs' BI toward using online learning.

H5: FC Efficacy will be a predictor of LSUs' BI toward using online learning.

Venkatesh et al. (2003) define performance expectancy as how users perceive that adopting the new system will help them perform specific tasks. Effort expectancy is the ease with which the users will find the new system; facilitating conditions refer to the perceptions of the users regarding the availability of support and resources required to assist in the use of the new system-these influence the behavioural intentions of the user to use the system or not.

\section{METHODOLOGY}

A cross-sectional descriptive study focusing on students' perception regarding remote-based learning was conducted in October 2020. The quantitative study employed an adapted UTAUT model to guide the research process. A sample of 600 undergraduate students registered for the 2019-2020 academic year provided the study's population. The researcher was granted permission to research by the Research and Innovation office. Participants were invited to participate in the study, and a total of 314 questionnaires were completed. The students were notified that participating in the study was voluntary, that their responses were confidential, and their identities were anonymous. The questionnaire was adapted from Ramli et al. (2020) and shared with the participants through Google Forms to observe COVID-19 lockdown restrictions. The study used a 30-item questionnaire with nine thematic areas: demographics and personal characteristics; access to devices and the internet; personal experience and engagement with Moodle. The other themes covered include Moodle's success in compensating for suspended face-to-face teaching, the efficiency of instruction and knowledge of Moodle; attitudes towards Moodle, barriers to use of Moodle; motivation to continue using post the pandemic. The instrument used various forms of questioning, such as multiple choice and Likert scale. A Likert scale of 1-5 was used where 1 represents Strongly Disagree, and 5 represents Strongly Agree. The Statistical Package of Social Science (SPSS version 22) was used to analyse the data. Data analysis involved computing percentages, frequencies and correlations between the constructs.

\section{Analysis of the Measurement Instrument}

The model's five variables were used to examine the 314 responses using a Cronbach's $\alpha$. The instrument signified good internal consistency with an average score of 0.877 , as shown in Table 1 . The internal reliability values were measured using Cronbach's alpha coefficient and values ranged between 0.702 to 0.869 were obtained. These exceeded Chua (2006)'s recommended threshold of 0.60. The instrument's validity is confirmed when Cronbach Alpha values are more than 0.6 (Chua, 2006). A high value depicts the correlatedness of variables within a single factor. In this study, the Cronbach Alpha value indicates that the instrument measured a common factor related to the student's perceptions towards e-learning adoption. The instrument demonstrated convergent validity as all the construct values were higher than the recommended threshold of 0.60 . The actual values ranged from 0.786 to 0.955 . Therefore, the instrument demonstrated good levels of consistency, reliability and validity.

\section{RESULTS}

More than half (56.4\%) of the 314 participants were females, while males constituted $44.6 \%$. The ages of the participants were as follows: 18 to 24 years (32.5\%), 25 to 30 years (28\%), 30 to 40 years $(27.4 \%)$ and over 40 years $(12.1 \%)$. The mobile phone is the most affordable ICT device; $65 \%$ of the student's accessed Moodle through the mobile phone; close to half (45\%) of the students had access to a laptop, while $10 \%$ had access to a desktop. The results show that $87 \%$ of the students could access the internet through mobile data, and only $13 \%$ had access to WiFi at home. Again over $72 \%$ of the participants agreed that the home environment was not conducive for learning. The results show that 
Table 1. Reliability and validity analysis of the instrument

\begin{tabular}{|c|c|c|c|}
\hline Variables & Consistency & Composite Reliability & Convergent Validity \\
\hline Performance Expectancy & 0.975 & 0.824 & 0.903 \\
\hline Effort Expectancy & 0.875 & 0.702 & 0.786 \\
\hline Facilitating Conditions-Support & 0.788 & 0.848 & 0.930 \\
\hline Facilitating Conditions-Access & 0.922 & 0.872 & 0.955 \\
\hline Facilitating Conditions-Efficacy & 0.869 & 0.869 & 0.879 \\
\hline
\end{tabular}

Table 2. Regression analysis (Dependent variable: $\mathrm{BI}$ )

\begin{tabular}{|c|c|c|c|c|}
\hline Hypothesis & Relationship & Coefficient $(\beta)$ & t value & Result \\
\hline $\mathrm{H} 1$ & $\mathrm{PE} \rightarrow \mathrm{BI}$ & 0.457 & 3.587 & Accept \\
\hline $\mathrm{H} 2$ & $\mathrm{EE} \rightarrow \mathrm{BI}$ & 0.280 & 2.578 & Accept \\
\hline $\mathrm{H} 3$ & $\mathrm{FCS} \rightarrow \mathrm{BI}$ & 0.325 & 3.035 & Accept \\
\hline $\mathrm{H} 4$ & $\mathrm{FCA} \rightarrow \mathrm{BI}$ & 0.295 & 2.430 & Accept \\
\hline $\mathrm{H} 5$ & $\mathrm{FCE} \rightarrow \mathrm{BI}$ & 0.398 & 3.579 & Accept \\
\hline
\end{tabular}

Note PE - Performance Expectancy, EE - Effort Expectancy, FCS - Facilitating Condition

Support, FCA - Facilitating Condition Access, FCE - Facilitating Condition Efficacy

${ }^{*} \mathrm{p}<.05 .{ }^{* *} \mathrm{p}<.01 .{ }^{* * *} \mathrm{p}<.001$.

$85 \%$ of the participants had no prior experience using Moodle or any other e-learning platforms before the COVID-19 outbreak. The majority of the students $(65.7 \%)$ preferred blended learning, $21 \%$ opted for a fully online environment, and $5 \%$ opted for traditional face-to-face learning. Most (72\%) of the students indicated that the lecturers did not show enough experience in e-learning, so students were not satisfied with online learning. Over two thirds (66\%) of participants highlighted that they were not confident with using Moodle. Lecturers' feedback was cited by $63 \%$ of the participants as an impediment to Moodle acceptance. Only $23 \%$ of the students reported that their lecturers used video conferencing software.

\section{Testing the Model}

The path Coefficient for each construct is shown in Table 2 through regression analysis. The results showed that Performance Expectancy $(\beta=.457, \mathrm{p}<.001)$ positively affects the student' behavioural intention to use Moodle for remote learning. This finding confirms the validity of the $\mathrm{H} 1$ hypothesis. The results showed that Effort Expectancy $(\beta=.280, \mathrm{p}<.001)$ positively affects the student' behavioural intention to use Moodle for remote learning, thereby supporting the validity of $\mathrm{H} 2$. Thus, students expect Moodle to be easy to use, increasing their behavioural intention to use the LMS. The Facilitating Conditions' influence on students to use Moodle was evaluated with the following results: Facilitating Condition Support ( $\beta$ $=.325, \mathrm{p}<.001)$, Facilitating Condition Access $(\beta=.295, \mathrm{p}<.001)$ and Facilitating Condition Efficacy $(\beta=.398, \mathrm{p}<.001)$. The findings support the validity of the three hypotheses $\mathrm{H} 3-\mathrm{H} 5$. The results showed that all the three Facilitating Conditions constructs positively affected the student's behavioural intention to use Moodle. Therefore, students are likely to use Moodle if they perceive that there is adequate organisational, technical support, and conducive policies to support online learning.

\section{DISCUSSION}

The results show that all the five constructs of the adapted model statistically influenced the student's behavioural intention to use Moodle. Results show that performance expectancy is the dominant determinant of Moodle usage. Higher Moodle adoption rates are achieved when the students believe that its usage will improve their performance and that less effort will be required. The facilitating conditions constructs were also significant determinants of the student's behavioural intention to use Moodle. Thus, the usage of Moodle by the student was affected by facilitating conditions such as access to devices, lack of support, low efficacy, high data costs, lecturer feedback, among others. The results are consistent with several studies such as Abu-Al-Aish and Love (2013); Kurt and Tingöy (2017); Nistor et al. (2014); Magsamen-Conrad et al. (2015); Tan (2013), Attuquayefio and Addo (2014) who found out that performance expectancy and facilitating conditions were significant determinants. Access to appropriate devices that can facilitate effective learning by students in developing countries is a challenge. Survey results confirmed this, as not all students could access a smartphone, a laptop, or Wi-Fi. The results show a low (45\%) laptop ownership rate compared to Vitoria et al. (2018), who established that over $84 \%$ of the students owned a laptop, while the smartphone ownership rates are almost the same. Again, lack of access to devices and training was noted by Lee (2008), who argued that institutions should provide devices and training to support the usage of e-learning.

Access to technological devices was poor, and the results are consistent with work by Aboagye et al. (2020), Dube (2020 and Tanveer et al. (2020), who established that most students did not have access to devices such as computers and laptops and this made the shift to online learning challenging. About three-quarters (78\%) of the participants this study used mobile phones for learning, making it difficult to run some applications. Other scholars noted that using small screen devices could result in eye strain (Gon et al., 2017). This finding conflicts with observations by Eltayeb et al. (2020), who established that only $26 \%$ of Saudi Arabian students preferred to use smartphones for e-learning. About $65 \%$ of the participants in this study preferred blended learning. The results are different from observations by Eltayeb et al. (2020), who observed that $69 \%$ of the students preferred the traditional face-to-face lecture delivery and had negative impressions of e-learning. Lack of prior knowledge observed in the study is contrary to Salloum et al. (2018), who established that over $70 \%$ of students interviewed in a UAE study had good knowledge and experience with Moodle. The majority (77\%) of the participants thought that Moodle was not easy to use. This 
finding is inconsistent with that of Vitoria et al. (2018), who concluded that over $70 \%$ of the students found Moodle easy to use.

Higher data costs hindered LMS access, and this was similar to another study in Malaysia that also revealed that high data costs hindered learners from fully participating in online learning (Ramli et al., 2020). Tanveer et al. (2020) and Aboagye et al. (2020) reported that students struggled to buy internet data as most of their parents were out of employment as companies closed due to the COVID-19 pandemic. The Zimbabwean government should provide subsidised data for students by partnering with internet service providers like Malaysia's government, offering daily 1GB free of data (Ramli et al., 2020). Regarding internet speed, $78 \%$ of the students agreed that slow internet speed hindered Moodle adoption. The findings are contrary to those of Eltayeb et al. (2020), who established that $64 \%$ of the students agreed that the internet speed was adequate for lecture attendance without interruption. In their study, Basilaia and Kvavadze (2020) reported a steady and successful transition to online learning by 950 students in Georgia. More than two-thirds (66\%) of the study participants spent more than two hours a week on the internet. This shows the student's potential to use e-learning platforms.

Poor lecturer feedback resulted in an unpleasant learning experience. Hurlbut (2018) noted that instructor feedback was one of the top predictors of online learning adoption highlighted by students who successfully embraced an online course. These findings support work by Al-Araibi et al. (2019), who noted that $45 \%$ of e-learning projects in developing countries fail due to technological limitations, with only $15 \%$ considered successful. Regardless of these impediments, $81 \%$ of the students believed that e-learning should be integrated into their courses. A similar study in Guyana by Thomas et al. (2013) revealed that the facilitating conditions were significant predictors of remote learning adoption.

\section{LIMITATIONS}

The findings are based on a study conducted at one institution; for the results' generalisability, a multi-university study should be conducted. The moderating variables found in the original UTAUT model were not used, and future studies could examine their effect.

\section{RECOMMENDATIONS}

The University should look beyond the pandemic and provide the support that bolsters the lecturer's competency in using the e-learning platform, motivating the students and ensuring utilisation. The institution should review its curriculum, which was developed entirely for face-to-face learning. A multi-stakeholder approach involving institutions, government, development partners, and telecommunications companies is required to build a resilient digital education system to solve some of the students' challenges. The institution could partner with some technology vendors to offer laptops on credit to support remote learning during the pandemic. Policies that promote the use and adoption of e-learning, including redesigning the curriculum to support ubiquitous learning, should be developed.

\section{CONCLUSION}

The study applied an adapted UTAUT model to establish the student's perceptions regarding e-learning adoption. The results show that Performance Expectancy, Effort Expectancy, and Facilitating Condition positively influenced the student's intention to use Moodle. However, the study did not use the moderating variables. The study contributes to the knowledge body on e-learning implementation in developing countries during COVID-19. As students learn from home away from the institution's infrastructure, the government and other stakeholders should support them. The result shows that students were not satisfied with the migration to the digital environment due to a lack of access to learning resources. This resulted in a significant loss of learning. Nevertheless, the majority of the students preferred blended learning. This study's output provides valuable information to policymakers and researchers regarding students' perceptions and the state of e-learning at institutions of higher learning. Future studies could evaluate the effectiveness of the current assessment methods used in developing countries during the pandemic.

Funding: Author received no financial support for the research and/or authorship of this article.

Declaration of interest: Author declares no competing interest.

Data availability: Data generated or analysed during this study are available from the author on request.

\section{REFERENCES}

Aboagye, E., Yawson, J., \& Appiah, K. (2020). COVID-19 and Elearning the challenges of Students in tertiary institutions in Ghana. Social Education Research, 1(1), 109-115. https://doi.org/10.37256/ ser.122020422

Abu-Al-Aish, A., \& Love, S. (2013). Factors influencing students acceptance of m-learning: An investigation in higher education. The International Review of Research in Open and Distributed Learning, 14(5), 82-107. https://doi.org/10.19173/irrodl.v14i5.1631

Akuratiya, D. A., \& Meddage, D. (2020). Students' Perception of Online Learning during COVID-19 Pandemic: A Survey Study of IT Students. International Journal of Research and Innovation in Social Science (IJRISS), IV(IX), 775-778. https://doi.org/10.21203/rs.3.rs41178/v1

Al-Araibi, A. A. M., Naz'ri, B., Mahrin, M., \& Yusoff, R. C. M. (2019). Technological aspect factors of Elearning readiness in higher education institutions: Delphi technique. Education and Information Technologies, 24(1), 567-590. https://doi.org/10.1007/s10639-0189780-9

Almaiah, M., Al-Khasawneh, A., \& Althunibat, A. (2020). Exploring the critical challenges and factors influencing the E-learning system usage during the COVID-19 pandemic. Education and Information Technologies, 25, 5261-5280. https://doi.org/10.1007/s10639-02010219-y

Alqahtani, A., \& Rajkhan, A. (2020). E-Learning Critical Success Factors during the COVID-19 Pandemic: A Comprehensive Analysis of E-Learning Managerial Perspectives. Education Sciences, 10(216), 1-16. https://doi.org/10.3390/educsci10090216 
Attuquayefio, S., \& Addo, H., (2014). Using the UTAUT model to analyse students' ICT adoption. International Journal of Education and Development using Information and Communication Technology, 10(3), 75-86

Anderson, B. (2005). New Zealand: Is online education a highway to the future? In A. Carr-Chelman, Global Perspectives on E-Learning: Rhetoric and Reality (pp. 163-178). Thousand Oaks.

Basilaia, G., \& Kvavadze, D. (2020). Transition to online education in schools during a SARS-CoV-2 Coronavirus (COVID-19) pandemic in Georgia. Pedagogical Research, 5(4), 1-9. https://doi.org/10.29333/pr/7937

businesstech. (2020). 730,000 laptops to be given to South African students for online learning. https://businesstech.co.za/news/technology/ 431856/730000-laptops-to-be-given-to-south-african-studentsfor-online-learning/

Chua, Y. P. (2006). Methods and Statistics Research: Book 1. Research Methods. McGraw Hill.

Chaka, C. (2020). Higher education institutions and the use of online instruction and online tools and resources during the COVID-19 outbreak - an online review of selected U.S. and SA's universities. Research Square, 1(46).

Eltayeb, L., Alharthi, N., Elmosaad, Y., \& Waggiallah, H. (2020). Students' perception of e. learning and remote exams during COVID-19 outbreak 2020. International Journal of Pharmaceutical and Phytopharmacological Research (eIJPPR), 10(5), 142-148.

McCarthy, N. (2019). The cost of mobile internet around the world. Forbes. https://www.forbes.com/sites/niallmccarthy/2019/03/05/ the-cost-of-mobile-internet-around-the-worldinfographic/?sh=37176a4f226e

Gamage, K., Wijesuriya, D., Ekanayake, S., Rennie, A., Lambert, C., \& Gunawardhana, N. (2020). Online Delivery of Teaching and Laboratory Practices: Continuity of University Programmes during COVID-19 Pandemic. Education Sciences, 10(291), 1-9. https://doi.org/10.3390/educsci10100291

Gelles, L., Lord, S., Hoople, G., Chen, D., \& Mejia, J. (2020). Compassionate Flexibility and Self-Discipline: Student Adaptation to Emergency Remote Teaching in an Integrated Engineering Energy Course during COVID-19. Education Sciences, 10(304), 1-23. https://doi.org/10.3390/educsci10110304

Gon, S., \& Rawekar, A. (2017). Effectivity of E-Learning through Whatsapp as a Teaching-Learning Tool. MVP Journal of Medical Sciences, 4(1), 19-25. https://doi.org/10.18311/mvpjms/0/v0/i0/ 8454

Gupta, M., Jankie, S., Pancholi, S., Talukdar, D., Sahu, P., \& Sa, B. (2020). Asynchronous Environment Assessment: A Pertinent Option for Medical and Allied Health Profession Education During the COVID-19 Pandemic. Education Sciences, 10(352), 1-14. https://doi.org/10.3390/educsci10120352

Harrell, P., \& Harris, M. (2006). Teacher preparation without boundaries: A two-year study of an online teacher certification program. Journal of Technology and Teacher Education, 14(4), 755-774.

Hoque, S., \& Alam, S. (2010). The Role of Information and Communication Technologies (ICTs) in Delivering Higher Education - A Case of Bangladesh. International Education Studies, 3(2), 97-106. https://doi.org/10.5539/ies.v3n2p97
Hurlbut, A. R. (2018). Online vs traditional learning in teacher education: a comparison of student progress. American Journal of Distance Education, 32(4), 248-266. https://doi.org/10.1080/ 08923647.2018.1509265

Internetworldstats. (2020). Africa. https://www.internetworldstats. com/africa.htm

Kurt, E. O., \& Tingöy, O. (2017). The acceptance and use of a virtual learning environment in higher education: an empirical study in Turkey and the UK. International Journal of Educational Technology in Higher Education, 14, 26. https://doi.org/10.1186/s41239-017-0064-

Lee, Y. (2008). The role of perceived resources in online learning adoption. Computers \& Education, 50(4), 1423-1438. https://doi.org/10.1016/j.compedu.2007.01.001

Li, C., \& Lalani, F. (2020). The COVID-19 pandemic has changed education forever. This is how. https://www.weforum.org/agenda/2020/04/ coronavirus-education-global-COVID19-online-digital-learning/

Liebenberg, J., Benade, T., \& Ellis, S., (2018). Acceptance of ICT: Applicability of the Unified Theory of Acceptance and Use of Technology (UTAUT) to South African Students. The African Journal of Information Systems, 10(3), 160-173.

Magsamen-Conrad, K., Upadhyaya, S., Joa, C. Y., \& Dowd, J. (2015). Bridging the divide: using UTAUT to predict multigenerational tablet adoption practices. Computers in Human Behavior, 50, 186-196.

Maphosa, V. (2020). Teachers' Perspectives on Remote-based Teaching and Learning in the COVID-19 era: Rethinking Technology Availability and Suitability in Zimbabwe. European Journal of Interactive Multimedia and Education, 1(2), 1-16.

Mouchantaf, M. (2020). The COVID-19 Pandemic: Challenges Faced and Lessons Learned Regarding Distance Learning in Lebanese Higher Education Institutions. Theory and Practice in Language Studies, 10(10), 1259-1266. https://doi.org/10.17507/tpls.1010.11

Neuwirth, L., Jovi'c, S., \& Mukherji, B. (2020). Reimagining higher education during and post-COVID-19: Challenges and opportunities. Journal of Adult and Continuing Education, 1-16. https://doi.org/10.1177/1477971420947738

Nistor, N., Lerche, T., Weinberger, A., Ceobanu, C., \& Heymann, O. (2014). Towards the integration of culture into the Unified Theory of Acceptance and Use of Technology. British Journal of Educational Technology, 45(1), 36-55.

OCHA. (2020, September 4). Zimbabwe situation. https://reports.unocha.org/en/country/zimbabwe/

Omer, M., Klomsri, K., Tedre, M., Popova, I., Klingberg-Allvin, M., \& Osman, F. (2015). E-learning opens the door to the Global Community: Novice Users' Experiences of E-learning in a Somali University. MERLOT Journal of Online Learning and Teaching, 11(2, 11(2), 267-279.

Oyediran, W., Omoare, A., Owoyemi, M., Adejobi, A., \& Fasasi, R. (2020). Prospects and limitations of e-learning application in private tertiary institutions amidst COVID-19 lockdown in Nigeria. Heliyon, 6, e05457. https://doi.org/10.1016/ j.heliyon.2020.e05457 
Ozadowicz, A. (2020). Modified Blended Learning in Engineering Higher Education during the COVID-19 Lockdown-Building Automation Courses Case Study. Education Sciences, 10(292), 1-20. https://doi.org/10.3390/educsci10100292

Raman, A. D. Y., Don, Y., Khalid, R., Hussin, F., Omar, M. S., \& Ghani, M. (2014). Technology acceptance on smart board among teachers in Terengganu using UTAUT Model. Asian Social Science, 10(11), 84-91. https://doi.org/10.5539/ass.v10n11p84

Ramli, M., Majid, M., \& Badyalina, B. (2020). Impeding factors towards the effectiveness of online learning during COVID-19 pandemic among social. International Journal of Learning and Development, 10(4), 37-49. https://doi.org/10.37256/ser.122020422

Reglitz, M. (2020). The human right to free internet access. Journal of Applied Philosophy, 30, 314-331. https://doi.org/10.1111/japp.12395

Rodriguesa, H., Almeida, F., Figueiredo, V., \& Lopes, S. (2019). Tracking e-learning through published papers: A systematic review. Computers \& Education, 136, 87-98. https://doi.org/10.1016/ j.compedu.2019.03.007

Salajegheh, A., Jahangiri, A., Dolan-Evans, E., \& Pakneshan, S. (2016). A combination of traditional learning and e-learning can be more effective in radiological interpretation skills in medical students: a pre-and post-intervention study. BMC Medical Education, 16(46), 17. https://doi.org/10.1186/s12909-016-0569-5

Salloum, S. A., Al-Emran, M., Shaalan, K., \& Tarhini, A. (2018). Factors affecting the E-learning acceptance: A case study from UAE. Education and Information Technologies, 24, 509-530. https://doi.org/10.1007/s10639-018-9786-3

Sintema, E. (2020). Effect of COVID-19 on the Performance of Grade 12 Students: Implications for STEM Education. Eurasia Journal of Mathematics, Science and Technology Education, 16(7), em1851. https://doi.org/10.29333/ejmste/7893

Swartz, B., Gachago, D., \& Belford, C. (2018). To care or not to carereflections on the ethics of blended learning in times of disruption: The ethics of care \& academic development. South African Journal of Higher Education, 32(6), 49-64. https://doi.org/10.20853/32-6-2659

Tam, G., \& El-Azar, D. (2020). 3 ways the coronavirus pandemic could reshape education. https://www.weforum.org/agenda/2020/03/3ways-coronavirus-is-reshaping-education-and-what-changesmight-be-here-to-stay/
Tan, P. (2013). Applying the UTAUT to Understand Factors Affecting the Use of English E-Learning Websites in Taiwan. SAGE Open, 3(4), 1-12. https://doi.org/10.1177/2158244013503837

Tan, P., Hay, D., \& Whaites, E. (2009). Implementing e-learning in a radiological science course in dental education: a short-term longitudinal study. Journal of Dental Education, 73(10), 1202-1212. https://doi.org/10.1002/j.0022-0337.2009.73.10.tb04812.x

Technomag. (2018). Smartphone Users Over 50\% In Zim. https://technomag.co.zw/2018/11/smartphone-users-over-50-inzim/?_cf_chl_jschl_tk_=a25a906ca8e290287d79cf841e11eba8ba 1109fe-1590911828-0-AeyETF0EGCEBsZg1CXxZrIYO7_ 6gKPN48_JIhQk4QsTrR_RyUAh2aKs7W9PUYujMyJLLSK5qzO zGZQ6-FhMTW_fKPPp9VZgdtFFEfUEFeg7BggFO89BW

Thomas, T., Singh, L., \& Gaffar, K. (2013). The utility of the UTAUT model in explaining mobile learning adoption in higher education in Guyana. International Journal of Education and Development using Information and Communication Technology, 9(3), 71-87.

United Nations University. (2020). Five facts on e-learning that can be applied to COVID-19. https://ehs.unu.edu/news/news/five-factson-e-learning-that-can-be-applied-to-COVID-19.html

universityworldnews. (2020). Zero-rating online learning - Not as simple as it sounds. https://www.universityworldnews.com/post.php? story $=20200408201225155$

Venkatesh, V., Morris, M., Davis, G., \& Davis, F. (2003). User acceptance of information technology: toward a unified view. Information Management, 27(3), 425-478. https://doi.org/10.2307/30036540

Veritas. (2013). Constitution of Zimbabwe 2013 http://www.veritaszim.net/node/315

Vitoria, L., Mislinawati, M., \& Nurmasyitah, N. (2018). Students' perceptions on the implementation of e-learning: Helpful or unhelpful? The 6th South East Asia Design Research International Conference (6th SEA-DR IC) (pp. 1-6). IOP Publishing. https://doi.org/10.1088/1742-6596/1088/1/012058

World Bank. (2020). Connecting for Inclusion: Broadband Access for All. https://www.worldbank.org/en/topic/digitaldevelopment/brief/c onnecting-for-inclusion-broadband-access-for-all 